\title{
The Electrochemistry of Simple Inorganic Molecules in Room Temperature Ionic Liquids
}

\author{
Debbie S. Silvester, Emma I. Rogers, Laura E. Barrosse-Antle, \\ Tessa L. Broder and Richard G. Compton* \\ Physical and Theoretical Chemistry Laboratory, University of Oxford, \\ South Parks Road, Oxford OXI 3QZ, United Kingdom
}

\begin{abstract}
A eletroquímica de compostos inorgânicos simples em líquidos iônicos a temperatura ambiente (RTIL) é revisada e alguns trabalhos novos nesta área são apresentados. Este artigo focaliza a comparação entre o comportamento eletroquímico em RTILs e em solventes apróticos convencionais. Alguns compostos (iodetos, $\mathrm{O}_{2}, \mathrm{NO}_{2}, \mathrm{SO}_{2}, \mathrm{NH}_{3}$ ) apresentam reações e mecanismos similares em RTILs e em solventes apróticos (como é observado para compostos orgânicos). Entretanto, outras espécies (nitratos, $\mathrm{PCl}_{3}, \mathrm{POCl}_{3}$ ) mostram comportamento excepcionalmente diferente em relação aos solventes tradicionais. Isto torna os RTILs um meio promissor para o estudo de compostos inorgânicos, e destaca a necessidade de maiores investigações nesta área.

The electrochemistry of simple inorganic compounds in room temperature ionic liquids (RTILs) is reviewed and some new work in this area is presented. This paper focuses on the comparison between electrochemical behaviour in RTILs and in conventional aprotic solvents. Some compounds (iodides, $\mathrm{O}_{2}, \mathrm{NO}_{2}, \mathrm{SO}_{2}, \mathrm{NH}_{3}$ ) display similar reactions and mechanisms in RTILs as in aprotic solvents (as is observed for organic compounds). However other species (nitrates, $\mathrm{PCl}_{3}, \mathrm{POCl}_{3}$ ) show remarkably different behaviour to traditional solvents. This makes RTILs very promising media for the study of inorganic compounds, and highlights the need for more investigations in this exciting area.
\end{abstract}

Keywords: Room Temperature Ionic Liquids, inorganic compounds, electrochemistry, voltammetry, gas sensing, mechanistic studies

\section{Introduction}

Room temperature ionic liquids (RTILs) are composed entirely of ions, and exist in the liquid state at and around room temperature. They are comprised of a bulky asymmetric organic cation, and a weakly-coordinating inorganic/organic anion. The structures of some of the most commonly used cations and anions are shown in Figure 1. The large number of combinations possible allows for the ability to fine-tune the solvent properties for a specific purpose, creating socalled "designer solvents". ${ }^{1}$ RTILs also have a number of interesting physical properties, including low-volatility, high thermal stability, high viscosity, high polarity, high intrinsic conductivity and a wide electrochemical window. ${ }^{2}$ Their low volatility has allowed a recent study ${ }^{3}$ of solute solubility in RTILs using X-ray Photoelectron Spectroscopy (a technique usually only applied to solids) and also means they may have environmental benefits as "greener" alternatives to volatile organic solvents. ${ }^{4}$ Their high intrinsic conductivity means

*e-mail: richard.compton@chem.ox.ac.uk that no supporting electrolyte is required in electrochemical experiments, minimizing experimental set-up and waste. Due to the high stability of the cations and anions, the electrochemical window can be very wide ( $c a$. 4.5-6 V), ${ }^{5,6}$ and consequently some voltammetric peaks, which are normally out of the range of traditional solvents, may be observed. This has been exploited in many electrodeposition studies $^{7}$ of some metals and semi-conductors which were not possible to electrodeposit previously. RTILs have also been employed as a supporting electrolyte, e.g. in acetonitrile, which in the presence of some RTILs, allows an extended anodic window compared to tetrabutylammonium perchlorate (TBAP). ${ }^{8}$ Their low-volatility, high thermal stability and intrinsic conductivity make them potentially useful as electrolytes in gas sensors, ${ }^{9}$ an application which will be discussed in more detail in section 5. RTILs are also used in a range of other electrochemical applications such as electrolytes in lithium batteries, ${ }^{10}$ capacitors ${ }^{11}$ and solar cells. ${ }^{12}$ The electrochemical characteristics of RTILs have been more thoroughly discussed in a number of recent review papers. ${ }^{5,13}$ 
(a)<smiles>CCCCCCCCCCCCCC</smiles><smiles>CCC[N+](CC)(CC)CC</smiles><smiles>CCCC[n+]1ccccc1</smiles>
$\left[\mathrm{C}_{4} \mathrm{py}\right]^{+}$ $\left[\mathrm{N}_{a, b, c, d}\right]^{+}$

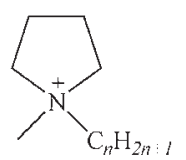

$\left[\mathrm{C}_{n} \text { mpyrr }\right]^{+}$

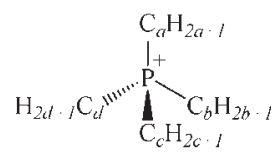

$\left[\mathrm{P}_{a, b, c, d}\right]^{+}$

(b)

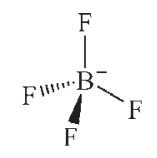

$\left[\mathrm{BF}_{4}\right]^{-}$

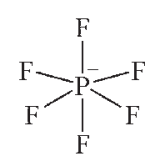

$\left[\mathrm{PF}_{6}\right]^{-}$

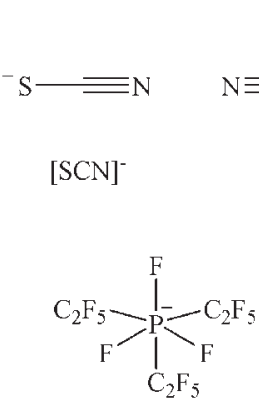

[FAP] ${ }^{-}$<smiles>N#C[N-]C#N</smiles>

$\left[\mathrm{N}(\mathrm{CN})_{2}\right]^{-}$<smiles>CCOS(=O)(=O)[O-]</smiles>

$\left[\mathrm{EtSO}_{4}\right]^{-}$

Figure 1. The structures of some cations and anions commonly employed in the synthesis of RTILs.

Generally, it has been found that electrochemical reactions and mechanisms of organic species in RTILs are the same as in conventional aprotic solvents, ${ }^{14,15}$ with any differences mainly due to the higher viscosity of the RTIL lowering the diffusion coefficients of the electroactive species. However, the study of reactions and mechanisms of inorganic species in RTILs is relatively unexplored. This report will focus on the recent developments in this area, looking at the electrochemistry of a range of solid, liquid and gaseous inorganic species in RTILs. Interestingly, we will show that the electrochemical behaviour of some inorganic species in ionic liquids is remarkably different to that in conventional aprotic solvents, so encouraging further studies of this type.

\section{Experimental}

Most of the experimental conditions and techniques employed have been reported in previous works. ${ }^{16-19}$ In

addition, the electrochemistry of $\mathrm{O}_{2}$ and $\mathrm{SO}_{2}$ gas was performed in a T-cell (reported previously), ${ }^{15}$ using a $\mathrm{Pt}$ microdisk (either 10 or $25 \mu \mathrm{m}$ diameter) as the working electrode, and a silver wire as a quasi-reference electrode. The working electrode was modified with a section of disposable micropipette tip, into which $20 \mu \mathrm{L}$ of the blank RTIL solvent was placed. The liquid was purged under vacuum for $c a .90 \mathrm{~min}$, after which gas was introduced through one arm of the cell. An outlet gas line led from the cell into a fume cupboard. Before voltammetric scans were undertaken, the ionic liquid was saturated with gas (typically for $c a .10 \mathrm{~min}$ for $\mathrm{O}_{2}$ and $30 \mathrm{~min}$ for $\mathrm{SO}_{2}$ ) as evidenced by stable maximum peak currents. Saturated solutions of potassium iodide, KI, and caesium iodide, CsI were prepared by placing ca. $2 \mathrm{mg}$ of solid in $100 \mu \mathrm{L}$ RTIL and stirred overnight in a foil-covered sealed vial. A volume of $20 \mu \mathrm{L}$ saturated solution was placed into the T-cell (described above) and purged under vacuum for $c a$. $90 \mathrm{~min}$. Electrochemical experiments were undertaken when the reductive baseline of the solution showed no obvious voltammetric features. Chronoamperometric transients were performed in the same manner as described in previous reports. ${ }^{16,17}$ The experimental data were fit to the Shoup and Szabo expression, ${ }^{20}$ as employed by Evans et al. ${ }^{21}$

The microdisk working electrodes were polished on soft lapping pads (Buehler, Illinois) with alumina slurries of size $1 \mu \mathrm{m}$ and $0.3 \mu \mathrm{m}$ respectively. The steady-state voltammetry of a $2 \mathrm{mmol} \mathrm{L}^{-1}$ solution of ferrocene in acetonitrile containing $0.1 \mathrm{~mol} \mathrm{~L}^{-1}$ tetra- $n$-butylammonium perchlorate (TBAP) was used to calculate the electrode diameter, adopting a value for the diffusion coefficient of $2.3 \times 10^{-9} \mathrm{~m}^{2} \mathrm{~s}^{-1}$ at $298 \mathrm{~K}^{22}$

\section{The Electrochemistry of Inorganic Salts in RTILs}

In order to understand the electrochemical reactions and mechanisms of simple solid inorganic species dissolved in RTILs, the electrochemistry of various nitrates and iodides was studied. Firstly, the electrochemistry of two nitrate salts, sodium nitrate and potassium nitrate (commonly used as fertilizers, explosives, in solid rocket propellants, and as a food preservative) has been reported recently. ${ }^{17}$ The ability to detect dissolved nitrates is of huge importance due to their potentially damaging effect on the environment, and many studies have been devoted to the electrochemical detection of nitrate species in water. ${ }^{23}$ Secondly, the electrochemistry of two iodide salts, potassium iodide (KI, used to protect the thyroid from radioactive iodine, and in the preparation of silver(I) iodide for use in photographic film) and caesium 
iodide (CsI, used in X-ray image intensifying, and in experimental particle physics) in an RTIL has been studied also, and these results, along with a summary of the results on nitrate salts are presented below.

\subsection{Oxidation of potassium nitrate}

Figure 2 shows the oxidation of a saturated solution of potassium nitrate $\left(\mathrm{KNO}_{3}\right)$ in the RTIL $\left[\mathrm{C}_{2} \mathrm{mim}\right]\left[\mathrm{NTf}_{2}\right]$ on a Pt electrode (diameter $10 \mu \mathrm{m}$ ) at a scan rate of $100 \mathrm{mV} \mathrm{s}^{-1}$. A steady-state oxidation peak was observed ${ }^{17}$ which was attributed to the direct oxidation of nitrate according to the following equation:

$\mathrm{NO}_{3}^{-} \rightarrow \mathrm{NO}_{2}+1 / 2 \mathrm{O}_{2}+e^{-}$

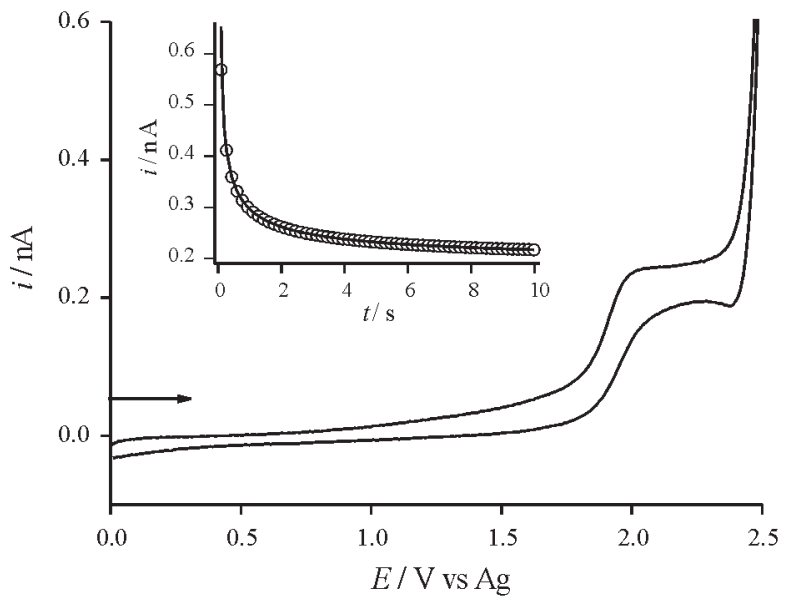

Figure 2. Cyclic voltammetry for the oxidation of a saturated solution of $\mathrm{KNO}_{3}$ in $\left[\mathrm{C}_{2} \mathrm{mim}\right]\left[\mathrm{NTf}_{2}\right]$ on a Pt microelectrode (diameter $10 \mu \mathrm{m}$ ) at a scan rate of $100 \mathrm{mV} \mathrm{s}^{-1}$. The inset shows the experimental (-) and fitted theoretical (o) chronoamperometric transients for the oxidation of $\mathrm{KNO}_{3}$ in $\left[\mathrm{C}_{2} \mathrm{mim}\right]\left[\mathrm{NTf}_{2}\right]$. The potential was stepped from 0 to $+2.2 \mathrm{~V}$.

The observation of this peak was significant, since it is believed that this is the first nitrate oxidation peak to be reported in the literature and is a direct consequence of the wide electrochemical window of the ionic liquid. A similar peak was observed for the oxidation of $\mathrm{NaNO}_{3} \cdot{ }^{17}$ Subsequently, a potential step was performed on the oxidative wave, revealing diffusion coefficients (at $298 \mathrm{~K}$ ) of $8.8 \times 10^{-12}$ and $9.0 \times 10^{-12} \mathrm{~m}^{2} \mathrm{~s}^{-1}$ and solubilities of 11.9 and $10.8 \mathrm{mmol} \mathrm{L}^{-1}$ in $\left[\mathrm{C}_{2} \mathrm{mim}\right]\left[\mathrm{NTf}_{2}\right]$ for $\mathrm{NaNO}_{3}$ and $\mathrm{KNO}_{3}$ respectively.

\subsection{Reduction of sodium nitrate}

In the same report, ${ }^{17}$ the reduction of $\mathrm{NO}_{3}^{-}$was also studied. Figure 3 shows cyclic voltammetry for the reduction of a saturated solution of $\mathrm{NaNO}_{3}$ in $\left[\mathrm{C}_{2} \mathrm{mim}\right]$ $\left[\mathrm{NTf}_{2}\right]$ on a $10 \mu \mathrm{m}$ diameter Pt electrode at a scan rate of
$1 \mathrm{~V} \mathrm{~s}^{-1}$. An unusual-shaped reduction feature was observed, which had several anodic peaks on the reverse scan (a close-up view is shown in the inset to Figure 3 ). These peaks were very similar to those observed previously in melts of the same compounds at temperatures of 623-773 K. ${ }^{24}$ Accordingly, the reduction was suggested ${ }^{17}$ to follow the equation:

$2 \mathrm{Na}^{+}+\mathrm{NO}_{3}^{-}+2 e^{-} \rightarrow \mathrm{Na}_{2} \mathrm{O}+\mathrm{NO}_{2}^{-}$

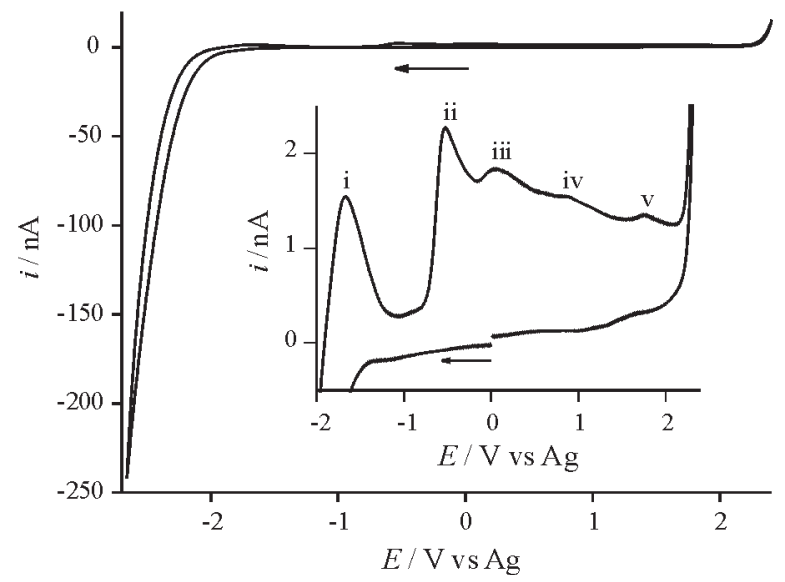

Figure 3. Cyclic voltammetry for the reduction of a saturated solution of $\mathrm{NaNO}_{3}$ in $\left[\mathrm{C}_{2} \mathrm{mim}\right]\left[\mathrm{NTf}_{2}\right]$ at a Pt microelectrode (diameter $10 \mu \mathrm{m}$ ). Scan rate: $1 \mathrm{~V} \mathrm{~s}^{-1}$.

The anodic peaks were identified ${ }^{17}$ as the oxidations of: (i) sodium oxide, (ii) sodium peroxide, (iii) sodium superoxide, (iv) nitrite, $\mathrm{NO}_{2}^{-}$, and (v) nitrate, $\mathrm{NO}_{3}^{-}$. The same peaks were observed for the reduction of $\mathrm{KNO}_{3}$, and all equations were given in the previous report. ${ }^{17}$ In order to confirm the proposed reaction mechanisms, X-ray Photoelectron Spectroscopy (XPS) was then performed on the Pt electrode. A large Pt disk electrode (6 mm diameter) was used as a working electrode, and the potential was held at $-2.8 \mathrm{~V}$ for 10 minutes. The electrode was then analysed by XPS, revealing that sodium (I) oxide, $\mathrm{Na}_{2} \mathrm{O}$, a compound which has shown use for hydrogen storage, ${ }^{25}$ was likely deposited on the Pt electrode following the reduction, supporting the identification of peaks (i), (ii) and (iii). This work is significant, since this shows that the ionic liquid behaved less like an aprotic solvent, but more like a melt in this case. This could substantially reduce the harsh conditions required to study these compounds, and suggests that RTIL solvents may have significant advantages over conventional solvents in other similar studies.

\subsection{Oxidation of inorganic iodides}

A second set of inorganic salts (iodides) was also studied to compare the reactions and mechanisms in RTILs 
and aprotic solvents. Figures $4 \mathrm{a}$ and $4 \mathrm{~b}$ show the oxidation of saturated solutions of potassium iodide (KI) and caesium iodide (CsI) respectively in the RTIL $\left[\mathrm{C}_{4} \operatorname{mim}\right]\left[\mathrm{NTf}_{2}\right]$ on a $\mathrm{Pt}$ microdisk electrode (diameter $10 \mu \mathrm{m}$ ) at a scan rate of $1 \mathrm{~V} \mathrm{~s}^{-1}$. Two transient-shaped oxidation peaks are observed in each voltammogram, and are attributed to the following processes:

$$
\begin{aligned}
& 3 \mathrm{I}^{-}-2 e^{-} \rightarrow \mathrm{I}_{3}^{-} \\
& \mathrm{I}_{3}^{-}-e^{-} \rightarrow 3 / 2 \mathrm{I}_{2}
\end{aligned}
$$
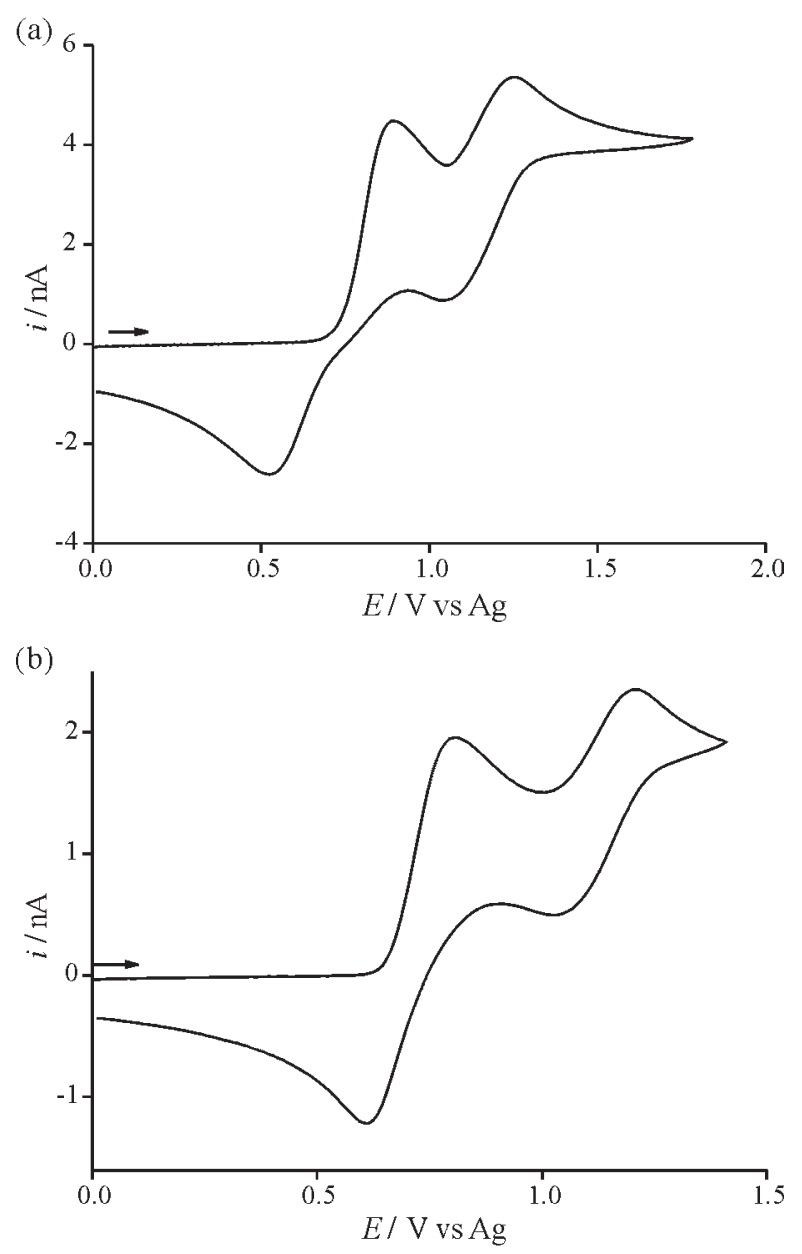

Figure 4. Cyclic voltammetry for the oxidation of saturated solutions of (a) $\mathrm{KI}$ and (b) $\mathrm{CsI}$ in $\left[\mathrm{C}_{2}\right.$ mim $]\left[\mathrm{NTf}_{2}\right]$ on a Pt microelectrode (diameter $10 \mu \mathrm{m})$ at a scan rate of $1 \mathrm{~V} \mathrm{~s}^{-1}$.

The mechanism presented in equations (3) and (4) is identical to that obtained for the oxidation of iodide in acetonitrile ${ }^{26}$ and in $\left[\mathrm{C}_{4} \mathrm{mim}\right]\left[\mathrm{BF}_{4}\right],{ }^{27}$ for the oxidation of chloride in $\left[\mathrm{C}_{4} \mathrm{mim}\right]\left[\mathrm{NTf}_{2}\right]^{28}$ and for the oxidation of bromide in acetonitrile, ${ }^{29}\left[\mathrm{C}_{4} \mathrm{mim}\right]\left[\mathrm{NTf}_{2}\right]^{29}$ and $\left[\mathrm{C}_{4} \mathrm{mpyrr}\right]$ $\left[\mathrm{NTf}_{2}\right] .{ }^{3}$ As the number of electrons transferred is known, a diffusion coefficient and concentration (or solubility) can be easily obtained from a potential step on the first oxidative wave. Results from transient fitting give diffusion coefficients of $1.23( \pm 0.05)$ and $1.33( \pm 0.05) \times 10^{-11} \mathrm{~m}^{2} \mathrm{~s}^{-1}$ at $298 \mathrm{~K}$, and solubilities in $\left[\mathrm{C}_{4} \operatorname{mim}\right]\left[\mathrm{NTf}_{2}\right]$ of 54 and $36 \mathrm{mmol} \mathrm{L}^{-1}$ for $\mathrm{KI}$ and CsI respectively. This study suggests that the mechanism for the oxidation of iodide is the same in RTILs as in conventional aprotic solvents.

\section{The Electrochemistry of Liquid Phosphorus Compounds in RTILs}

As another example of the different behaviour of ionic liquids compared to conventional solvents (c.f. nitrates, section 3.1 and 3.2), the electrochemistry of two liquids: phosphorus trichloride $\left(\mathrm{PCl}_{3}\right)$ and phosphorus oxychloride $\left(\mathrm{POCl}_{3}\right)$, was studied. ${ }^{19}$ These compounds hydrolyze rapidly in the presence of tiny amounts of water/moisture, so no detailed studies have been reported in conventional aprotic media. However, Amigues et al. ${ }^{30}$ showed that $\mathrm{PCl}_{3}$ and $\mathrm{POCl}_{3}$ were unusually stable in some RTILs, and as a result, we then studied the electrochemistry in detail for the first time. ${ }^{19} \mathrm{As}^{\mathrm{PCl}_{3}}$ and $\mathrm{POCl}_{3}$ are both important industrial chemicals (e.g. used in the manufacture of herbicides, insecticides and plasticizers for PVC), it seems worthwhile to study their electrochemical mechanisms and behaviour. A brief description of the results is presented below.

\subsection{Reduction and oxidation of phosphorus trichloride, $\mathrm{PCl}_{3}$}

Figure 5 shows cyclic voltammetry for the reduction of ca. $15 \mathrm{mmol} \mathrm{L}^{-1} \mathrm{PCl}_{3}$ in the RTIL $\left[\mathrm{C}_{4}\right.$ mpyrr] $\left.\mathrm{NTf}_{2}\right]$ on a gold microdisk electrode (diameter $=25 \mu \mathrm{m}$ ) at a scan rate of $100 \mathrm{mV} \mathrm{s}^{-1}$. A large reductive feature in the shape of a "split-wave" was seen, and two anodic peaks and a further cathodic peak were observed on the reverse scan. As this was the first detailed electrochemical study of $\mathrm{PCl}_{3}$, the mechanisms were largely unknown. To investigate this, potential step chronoamperometry was performed on the reductive wave (I), and revealed a diffusion coefficient of $3.1 \times 10^{-12} \mathrm{~m}^{2} \mathrm{~s}^{-1}$, and an electron count of one. Accordingly, the following mechanism was proposed: ${ }^{19}$

$$
\begin{aligned}
& \mathrm{PCl}_{3}+e^{-} \rightleftharpoons \mathrm{PCl}_{3}^{-} \\
& \mathrm{PCl}_{3}^{-} \rightleftharpoons \mathrm{Cl}^{-}+\mathrm{P}^{\mathrm{s}} \mathrm{Cl}_{2} \\
& \mathrm{Cl}^{-}+\mathrm{PCl}_{3} \rightleftharpoons \mathrm{PCl}_{4}^{-}
\end{aligned}
$$

Here, a parent molecule is reduced by one electron to form $\mathrm{PCl}_{3}^{-}$, which then dissociates to chloride and a 


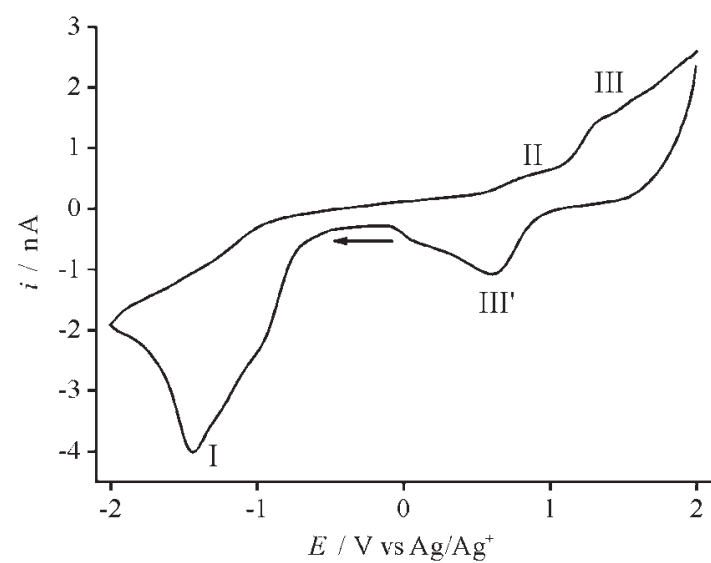

Figure 5. Cyclic voltammetry for the reduction of ca. $15 \mathrm{mmol} \mathrm{L}^{-1} \mathrm{PCl}_{3}$ in $\left[\mathrm{C}_{4}\right.$ mpyrr $]\left[\mathrm{NTf}_{2}\right]$ on a gold microelectrode (diameter $25 \mu \mathrm{m}$ ) at a scan rate of $100 \mathrm{mV} \mathrm{s}^{-1}$.

radical species, and then chloride attaches to another parent molecule to form $\mathrm{PCl}_{4}^{-}$. The reductive wave was successfully simulated using a digital simulation program following this scheme. This simulation gave rise to an anodic peak, which was positioned at the peak potential of wave II, and thus allowed the identification of peak II. The standard electrochemical rate constant, $k_{s}$, was found to be of the order $10^{-9} \mathrm{~cm} \mathrm{~s}^{-1}$, which is extremely small, and suggests that the cleavage of the $\mathrm{P}-\mathrm{Cl}$ bond may be concerted, where electron-transfer and bond breaking take place simultaneously. Peaks III and III' were later identified ${ }^{19}$ as the oxidation of $\mathrm{POCl}_{3}$ present in solution (see Section 4.2). The value of the diffusion coefficient was very small $\left(3.1 \times 10^{-12} \mathrm{~m}^{2} \mathrm{~s}^{-1}\right)$, even when compared to other charged species in RTILs. It is similar to that obtained for the self-diffusion coefficient of the RTIL $\left[\mathrm{C}_{4} \mathrm{mim}\right]\left[\mathrm{PF}_{6}\right]$ (rate at which the anion and cation move in the liquid), ${ }^{31}$ and suggests that the molecules may sit in the "holes" of the ionic liquid, and move with it; this might be why it is so stable in this medium.

\subsection{Reduction and oxidation of phosphorus oxychloride, $\mathrm{POCl}_{3}$}

In order to determine if any of the remaining peaks (III and III') were due to any oxidised forms of $\mathrm{PCl}_{3}$, the electrochemistry of $\mathrm{POCl}_{3}$ was studied. ${ }^{19}$ Typical voltammetry for the reduction and oxidation of $c a$. $15 \mathrm{mmol} \mathrm{L}^{-1} \mathrm{POCl}_{3}$ on a Au microdisk electrode (diameter $25 \mu \mathrm{m}$ ) at a scan rate of $100 \mathrm{mV} \mathrm{s}^{-1}$ is shown in Figure 6. A similar reduction feature to $\mathrm{PCl}_{3}$ (split-wave) was seen, with an electron count of 1 , and a diffusion coefficient of $2.2 \times 10^{-11} \mathrm{~m}^{2} \mathrm{~s}^{-1}$, as calculated by chronoamperometry. An identical one-electron mechanism to $\mathrm{PCl}_{3}$, equations (5)-(7), was proposed, ${ }^{19}$ and was also successfully simulated by digital simulation. For $\mathrm{POCl}_{3}$, the reaction was found to be slightly less shifted towards the product $\left(\mathrm{POCl}_{4}^{-}\right.$in this case). As is clearly observed in Figure 6, peaks $\mathrm{P}_{5}, \mathrm{P}_{6}$ and $\mathrm{P}_{7}$ are the oxidations of $\mathrm{POCl}_{3}$ parent molecules. The oxidations of $\mathrm{POCl}_{3}$ match that of peaks III and III' for $\mathrm{PCl}_{3}$ (Figure 5), and hence are identified as the oxidation of $\mathrm{POCl}_{3}$. Finally, peaks $\mathrm{P}_{3}$ and $\mathrm{P}_{4}$ were identified as the oxidation of chloride (studied as $\left[\mathrm{C}_{4} \mathrm{mpyrr}\right] \mathrm{Cl}$ ), ${ }^{19}$ further supporting the mechanism. It was also observed that the reduction of $\mathrm{POCl}_{3}$ was more "steady-state" like than $\mathrm{PCl}_{3}$, and corresponds well with the $D$ values, since $D$ for $\mathrm{POCl}_{3}$ is $c a$. ten times greater than $D$ of $\mathrm{PCl}_{3}$. It is believed that this is the first detailed electrochemical study of these phosphorus compounds in any solvent.

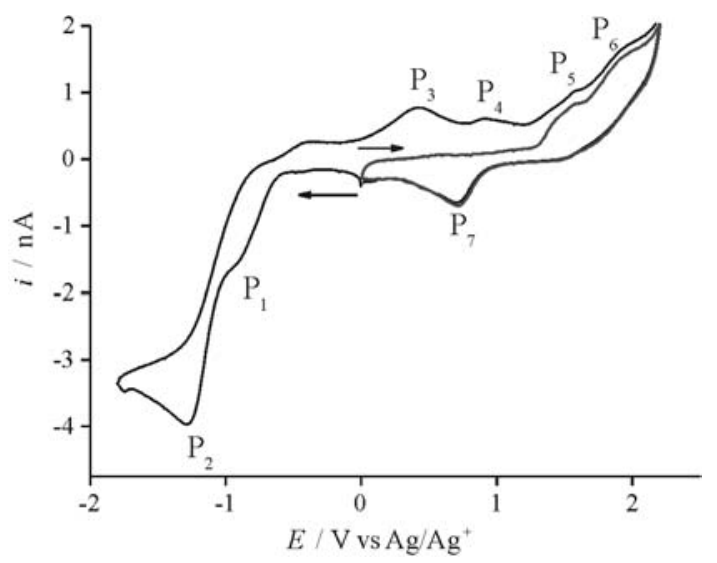

Figure 6. Cyclic voltammetry for the reduction and oxidation of $c a .15$ mmol L-1 $\mathrm{POCl}_{3}$ in $\left[\mathrm{C}_{4}\right.$ mpyrr] $\left[\mathrm{NTf}_{2}\right]$ on a gold microelectrode (diameter $25 \mu \mathrm{m})$ at a scan rate of $100 \mathrm{mV} \mathrm{s}^{-1}$.

\section{The Electrochemistry of Dissolved Gases in RTILs}

The ability to sense gases in the atmosphere is of huge importance in a variety of fields. In particular, when the gas is toxic and harmful to the environment, the detection of trace amounts of gas is vital to prevent danger to human health. There are many designs for gas sensors, most employing conventional solvents which cannot survive drastic temperature changes, i.e. extremely dry or humid conditions. Typically, a $\mathrm{H}_{2} \mathrm{SO}_{4} / \mathrm{H}_{2} \mathrm{O}$ mixture is used to match "usual" atmospheric conditions, but the sensor lifetime may be limited due to the tendency of the electrolyte to "dry-out" over time. The favourable properties of RTILs, such as the low-volatility, high thermal stability, intrinsic conductivity and wide potential windows, means that they may have significant advantages over traditional solvents in gas sensors. As a result, several researchers have investigated the use of RTILs as electrolytes in gas sensors. ${ }^{9,32}$ A practical drawback is that response times are slower due to the much higher viscosity of the RTIL 
compared to traditional solvents, and their sensitivity to moisture and impurities in the air may complicate their widespread use. The work reported in this section describes the electrochemical behaviour of four simple gases (oxygen, ammonia, nitrogen dioxide and sulphur dioxide) in several different RTILs. The behaviour is compared to that observed in conventional aprotic solvents.

\subsection{Reduction of oxygen}

The electrochemical reduction of oxygen has been extensively investigated in a variety of different solvents, and follows the simple one-electron mechanism:

$\mathrm{O}_{2}+e^{-} \rightarrow \mathrm{O}_{2}^{\text {sn }}$

Since the superoxide species $\left(\mathrm{O}_{2}^{\mathrm{sn}}\right)$ is known to readily react with water, ${ }^{33}$ the use of aprotic solvents is necessary to produce stable superoxide anions and electrochemically reversible voltammetry. This has been shown for the reduction of oxygen in the aprotic solvents acetonitrile, ${ }^{34-36}$ $N, N$-dimethylformamide, ${ }^{35,36}$ dimethyl sulfoxide, ${ }^{36}$ acetone ${ }^{36}$ pyridine ${ }^{36}$ and methylene chloride. ${ }^{36}$ To compare the behaviour in ionic liquids to that in aprotic solvents, we next study the reduction of oxygen in RTILs. Figure 7 shows typical cyclic voltammetry for the reduction of $\mathrm{O}_{2}$ on a Pt electrode (diameter $25 \mu \mathrm{m}$ ) at a scan rate of $1 \mathrm{~V} \mathrm{~s}^{-1}$ in (a) $\left[\mathrm{C}_{4} \mathrm{dmim}\right]\left[\mathrm{NTf}_{2}\right]$ and (b) $\left[\mathrm{C}_{4} \mathrm{mim}\right]\left[\mathrm{PF}_{6}\right]$. In $\left[\mathrm{C}_{4} \mathrm{dmim}\right]$ $\left[\mathrm{NTf}_{2}\right]$, the reduction of oxygen to superoxide is steadystate shaped, and the re-oxidation is highly transient shaped. In $\left[\mathrm{C}_{4} \mathrm{mim}\right]\left[\mathrm{PF}_{6}\right]$, both reduction and oxidation peaks are relatively broad and transient shaped. The asymmetry of the forward and reverse peaks in RTILs has been found ${ }^{37}$ to be due to the large discrepancy in the diffusion coefficients of $\mathrm{O}_{2}$ and $\mathrm{O}_{2}^{\mathrm{sn}}$; they vary by a factor of thirty in some RTILs, compared to just three in acetonitrile. From potential step chronoamperometry, the diffusion coefficient of $\mathrm{O}_{2}$ at $298 \mathrm{~K}$ was found to be $1.18( \pm 0.10) \times 10^{-10}$ and 0.64 $( \pm 0.05) \times 10^{-10} \mathrm{~m}^{2} \mathrm{~s}^{-1}$, and the solubility was found to be $11.5( \pm 0.5)$ and $9.5( \pm 0.4) \mathrm{mmol} \mathrm{L}^{-1}$ in $\left[\mathrm{C}_{4} \mathrm{dmim}\right]\left[\mathrm{NTf}_{2}\right]$ and $\left[\mathrm{C}_{4} \mathrm{mim}\right]\left[\mathrm{PF}_{6}\right]$ respectively. Although the mechanism for $\mathrm{O}_{2}$ reduction is found to be the same in RTILs and conventional solvents, the different behaviour in the two RTILs suggests that the kinetics of diffusion for oxygen and superoxide is sensitive to the choice of the RTIL solvent.

\subsection{Oxidation of ammonia}

Ammonia is a highly toxic gas, which is used extensively in many applications such as refrigeration and fertilizer manufacture, ${ }^{38}$ and the ability to detect trace amounts of

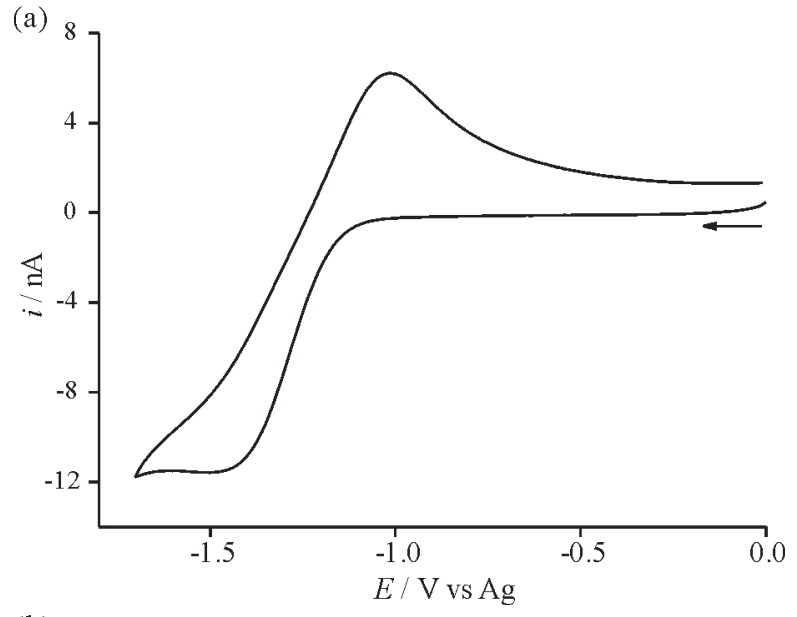

(b)

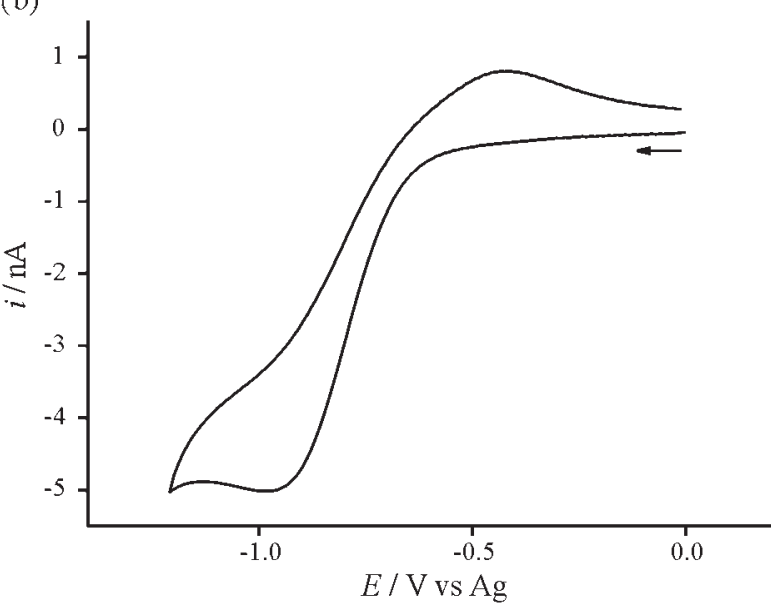

Figure 7. Cyclic voltammetry for the reduction of $100 \% \mathrm{O}_{2}$ gas in (a) $\left[\mathrm{C}_{4} \mathrm{dmim}\right]\left[\mathrm{NTf}_{2}\right]$ and (b) $\left[\mathrm{C}_{4} \mathrm{mim}\right]\left[\mathrm{PF}_{6}\right]$ at a Pt microelectrode (diameter $25 \mu \mathrm{m})$. Scan rate: $1 \mathrm{~V} \mathrm{~s}^{-1}$.

ammonia is of huge environmental importance. Various studies have focussed on the electrochemical oxidation of ammonia in alkaline solutions, ${ }^{39}$ and as a result, several protocols based on its determination via its direct oxidation have been developed. Mechanistic studies for the oxidation of ammonia have been reported in the aprotic solvents acetonitrile $(\mathrm{MeCN}),{ }^{40}$ dimethyl formamide (DMF), ${ }^{41}$ propylene carbonate (PC), ${ }^{42}$ and in the RTIL $\left[\mathrm{C}_{2} \mathrm{mim}\right]$ $\left[\mathrm{NTf}_{2}\right]{ }^{41}$ Very recently, we extended this study by looking at the oxidation of ammonia in five RTILs: $\left[\mathrm{C}_{4} \mathrm{mim}\right.$ ] $\left[\mathrm{BF}_{4}\right],\left[\mathrm{C}_{4} \operatorname{mim}\right][\mathrm{OTf}],\left[\mathrm{C}_{2} \mathrm{mim}\right]\left[\mathrm{NTf}_{2}\right],\left[\mathrm{C}_{4} \operatorname{mim}\right]\left[\mathrm{NTf}_{2}\right]$ and $\left[\mathrm{C}_{4} \operatorname{mim}\right]\left[\mathrm{PF}_{6}\right] .{ }^{18}$

Figure 8 shows the oxidation of ammonia $\left(10 \% \mathrm{NH}_{3}\right.$, $90 \% \mathrm{~N}_{2}$ ) on a Pt microdisk electrode $($ diameter $=10 \mu \mathrm{m})$ in the RTIL $\left[\mathrm{C}_{4} \mathrm{mim}\right]\left[\mathrm{BF}_{4}\right]$ at a scan rate of $10 \mathrm{~V} \mathrm{~s}^{-1}$. Peak I corresponds to the direct oxidation of ammonia, and peaks II, III and IV have been shown ${ }^{18}$ to be due to the following electro-generated products; the solvated proton $\left(\mathrm{H}\left[\mathrm{BF}_{4}\right]_{\mathrm{x}}\right)$, ammonium ion $\left(\mathrm{NH}_{4}^{+}\right)$and adsorbed hydrogen $\left(\mathrm{H}_{2}\right)$ respectively. Interestingly, the peaks observed in RTILs are 


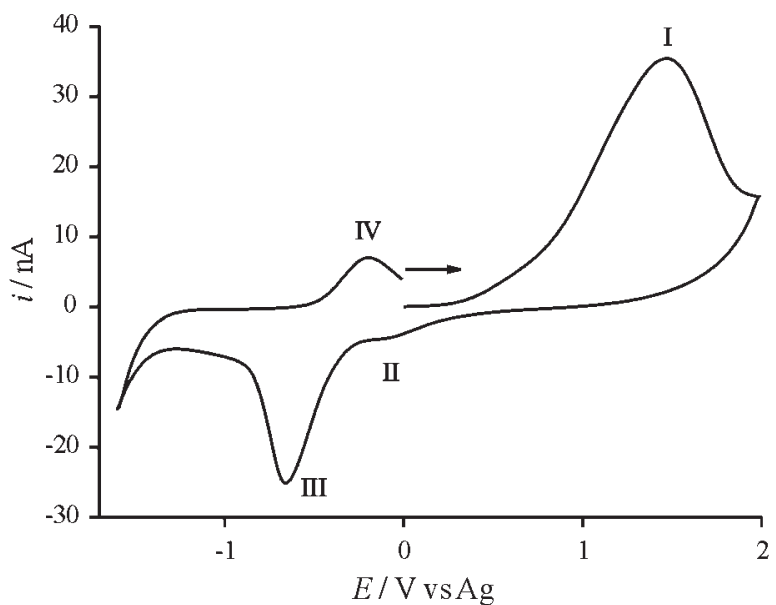

Figure 8. Cyclic voltammetry for the oxidation of $10 \% \mathrm{NH}_{3}$ gas $(90 \%$ $\mathrm{N}_{2}$ ) in $\left[\mathrm{C}_{4} \mathrm{mim}\right]\left[\mathrm{BF}_{4}\right]$ on a Pt microelectrode (diameter $10 \mu \mathrm{m}$ ) at a scan rate of $10 \mathrm{~V} \mathrm{~s}^{-1}$.

the same as those observed in conventional aprotic solvents, with the exception of peak II, which is only observed in RTIL media. It was then shown ${ }^{18}$ that the relative size of peak II $v s$. peak III increases with increasing scan rate, suggesting that the solvated proton is formed first, followed by proton transfer to form the ammonium ion. The following general reaction scheme was proposed ${ }^{18}$ for the oxidation of ammonia in RTIL media:

$$
\begin{aligned}
& \mathrm{NH}_{3}(\mathrm{~g})+3 \mathrm{~A}^{-} \rightarrow 1 / 2 \mathrm{~N}_{2}(\mathrm{~g})+3 \mathrm{HA}+3 e^{-} \\
& \mathrm{HA}+\mathrm{NH}_{3}(\mathrm{~g}) \rightleftharpoons \mathrm{NH}_{4}{ }^{+}+\mathrm{A}^{-} \\
& \mathrm{HA}+e^{-} \stackrel{\text { rds }}{\longrightarrow} \mathrm{A}^{-}+\mathrm{Pt}(\mathrm{H}) \rightarrow \mathrm{A}^{-}+1 / 2 \mathrm{H}_{2}(\mathrm{~g}) \\
& \mathrm{NH}_{4}^{+}+e^{-} \stackrel{\text { rds }}{\longrightarrow} \mathrm{NH}_{3}(\mathrm{~g})+\mathrm{Pt}(\mathrm{H}) \rightarrow \mathrm{NH}_{3}+1 / 2 \mathrm{H}_{2}(\mathrm{~g})
\end{aligned}
$$

where $\mathrm{A}^{-}=$the un-protonated anion, $\left[\mathrm{BF}_{4}\right]^{-}$, and $\mathrm{HA}$ is the

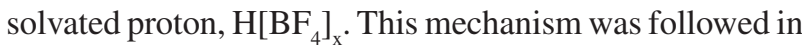
four of the RTILs studied. However, in $\left[\mathrm{C}_{4} \mathrm{mim}\right]\left[\mathrm{PF}_{6}\right]$, it is believed that the ammonium ion is formed first, followed by the solvated proton, $\mathrm{H}\left[\mathrm{PF}_{6}\right]_{\mathrm{x}} \cdot{ }^{18}$ These observations may help to understand both the role of the RTIL anion in reaction schemes and the relative stability of the electrogenerated protonated anion, helping towards developing a pH scale. Overall, the mechanism for the oxidation of ammonia is similar in RTILs and conventional solvents, but the formation of $\mathrm{NH}_{4}^{+}$proceeds via solvation of the proton by the RTIL anion in RTIL media.

\subsection{Oxidation of nitrogen dioxide}

Nitrogen dioxide $\left(\mathrm{NO}_{2}\right)$ is a brown toxic gas, which contributes to air pollution and causes damage to respiratory organs. The gas is emitted from cars, boilers and other combustion facilities, and the sensing/ determination of nitrogen dioxide in air is of huge importance. Several methods, including those based on electrochemistry, ${ }^{43}$ have been used to determine $\mathrm{NO}_{2}$, but there are relatively few studies reporting its oxidative or reductive mechanisms. In order to try to understand the oxidation and reduction mechanisms of $\mathrm{NO}_{2}$, the electrochemistry of $\mathrm{NO}_{2}$ gas was studied in an RTIL, and was reported recently. ${ }^{16}$ Figure 9 shows three repeat cyclic voltammograms for the oxidation of $100 \% \mathrm{NO}_{2}$ in $\left[\mathrm{C}_{2}\right.$ mim $]\left[\mathrm{NTf}_{2}\right]$ on a Pt microdisk electrode (diameter $10 \mu \mathrm{m})$ at a scan rate of $1 \mathrm{~V} \mathrm{~s}^{-1}$. A steady-state oxidation peak was observed, with a corresponding transient reduction peak which were suggested ${ }^{16}$ to be due to the following CE mechanism:

$\mathrm{N}_{2} \mathrm{O}_{4} \rightleftharpoons 2 \mathrm{NO}_{2} \rightleftharpoons 2 \mathrm{NO}_{2}^{+}+2 e^{-}$

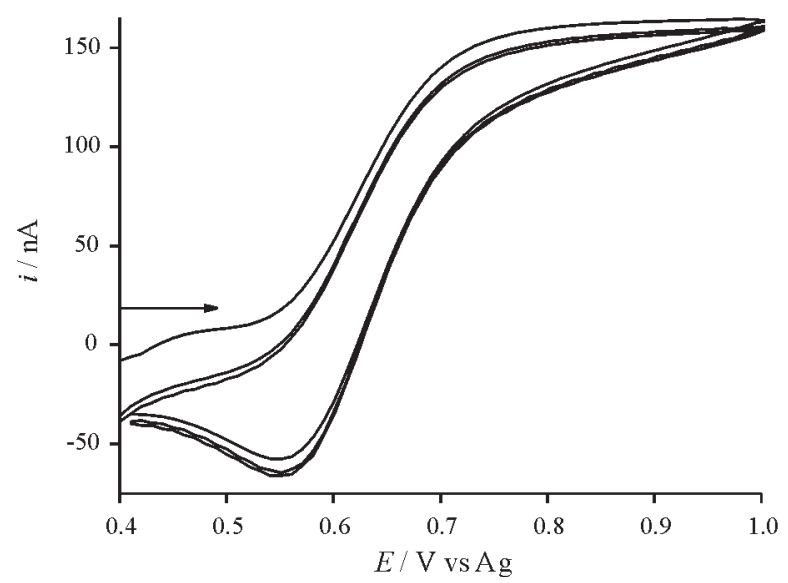

Figure 9. Three repeat cyclic voltammograms for the oxidation of $100 \%$ $\mathrm{NO}_{2}$ gas in $\left[\mathrm{C}_{2}\right.$ mim $]\left[\mathrm{NTf}_{2}\right]$ on a Pt microdisk electrode $($ diameter $=10 \mu \mathrm{m})$ at a scan rate of $1 \mathrm{~V} \mathrm{~s}^{-1}$.

It is thought that $\mathrm{NO}_{2}$ exists predominantly as its dimer, $\mathrm{N}_{2} \mathrm{O}_{4}$, at room temperature, and must undergo a dissociation reaction before the electrochemical step. Using potential step chronoamperometry, a diffusion coefficient at $298 \mathrm{~K}$ of $1.59 \times 10^{-10} \mathrm{~m}^{2} \mathrm{~s}^{-1}$ and a solubility of $51.2 \mathrm{mmol} \mathrm{L}^{-1}$ for $\mathrm{NO}_{2}$ in $\left[\mathrm{C}_{2} \mathrm{mim}\right]\left[\mathrm{NTf}_{2}\right]$ were calculated. ${ }^{16}$ The solubility is more than ten times greater than that observed in $\mathrm{KNO}_{3}-\mathrm{NaNO}_{3}$ melts $\left(5 \mathrm{mmol} \mathrm{L}^{-1}\right.$ at $573 \mathrm{~K}^{44}$ and $2 \mathrm{mmol} \mathrm{L}^{-1}$ at $523 \mathrm{~K}),{ }^{45}$ suggesting the possibility of using RTIL as favourable gas sensing media.

The oxidation mechanism is believed to be the same as that proposed for $\mathrm{N}_{2} \mathrm{O}_{4}$ (studied as a liquid) in a range of aprotic solvents, ${ }^{46,47}$ and the kinetics in the RTIL were found to be most similar to those in the aprotic solvent dichloromethane (DCM) ${ }^{47}$ However, the wide window 
of the ionic liquid allowed the observation of a second oxidation peak (believed to be the direct oxidation of $\mathrm{N}_{2} \mathrm{O}_{4}$ ) and a quasi-reversible reduction peak (the identity of which is as yet unconfirmed). It is believed that this is the first report of these two peaks, and shows that the wide windows of RTILs may have advantages over conventional solvents in allowing the observation of peaks which would otherwise have been curtailed by the decomposition of the electrolyte.

\subsection{Reduction of sulphur dioxide}

Sulphur dioxide $\left(\mathrm{SO}_{2}\right)$ is a colourless gas with a pungent odour, which dissolves readily in water and can be highly toxic when inhaled. It is of huge environmental concern, as it is converted to sulphuric acid, sulphur trioxide and sulphates and can contribute to acid rain. Atmospheric $\mathrm{SO}_{2}$ is mainly generated by the burning of coal and oil at power plants, copper smelting, and volcanic eruptions. There have been several reports focussed on its determination, some of which are based on electrochemical methods. ${ }^{48}$ The mechanism for the electro-reduction of $\mathrm{SO}_{2}$ has been extensively studied in a range of aprotic solvents, such as dimethylsulfoxide (DMSO) ${ }^{49,50} \mathrm{~N}, \mathrm{~N}$-dimethylformamide (DMF), ${ }^{50-52}$ hexamethylphosphoramide (HMPA) ${ }^{50,51}$ and acetonitrile $(\mathrm{MeCN}) .{ }^{51}$ All authors agree that the following one-electron reduction occurs in aprotic solvents:

$$
\mathrm{SO}_{2}+e^{-}=\mathrm{SO}_{2}^{\mathrm{sn}}
$$

This step is then followed by a number of chemical steps, resulting in the formation of several electroactive species, some of which are re-oxidised on the reverse voltammetric sweep. A detailed analysis and elucidation of the reduction mechanism is given by Potteau et al. ${ }^{50}$ who propose a general mechanism in all aprotic solvents.

To determine if the mechanism is the same in RTILs as in conventional solvents, the reduction of $\mathrm{SO}_{2}$ was studied in an RTIL. The reduction of $100 \% \mathrm{SO}_{2}$ gas in the RTIL $\left[\mathrm{C}_{4} \mathrm{mim}\right]\left[\mathrm{NO}_{3}\right]$ on a $\mathrm{Pt}$ microelectrode (diameter $10 \mu \mathrm{m}$ ) at a scan rate of $30 \mathrm{~V} \mathrm{~s}^{-1}$ is shown in Figure 10. A very large reduction peak is observed at $c a$. $-1 \mathrm{~V}$, with two broad oxidative waves on the reverse sweep. A relatively fast scan rate was necessary to observe both oxidative peaks clearly. From potential step chronoamperometry on the reductive wave, a diffusion coefficient of $5.0( \pm 0.8) \times$ $10^{-10} \mathrm{~m}^{2} \mathrm{~s}^{-1}$ and a very large solubility of $3100( \pm 450)$ mmol $\mathrm{L}^{-1}$ was calculated, suggesting that the RTIL medium may be very useful for the electrochemical sensing of small amounts of $\mathrm{SO}_{2}$. Although a full analysis of the electrochemical mechanism in this RTIL has not yet been carried out, the voltammetry observed is very similar to that obtained in conventional aprotic solvents, ${ }^{49-52}$ suggesting a similar, if not identical mechanism in $\left[\mathrm{C}_{4} \mathrm{mim}\right]\left[\mathrm{NO}_{3}\right]$ and conventional solvents. However, the kinetics are likely to differ due to the higher viscosity and slower diffusion in the RTIL medium.

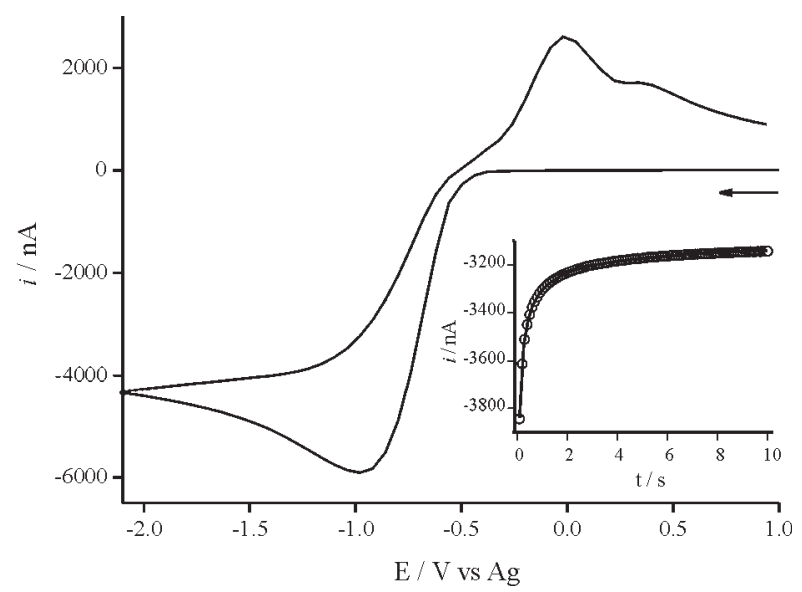

Figure 10. Cyclic voltammetry for the reduction of $100 \% \mathrm{SO}_{2}$ gas in $\left[\mathrm{C}_{4} \mathrm{mim}\right]\left[\mathrm{NO}_{3}\right]$ on a Pt microelectrode (diameter $10 \mu \mathrm{m}$ ) at a scan rate of $30 \mathrm{~V} \mathrm{~s}^{-1}$. The inset shows the experimental (-) and fitted theoretical (o) chronoamperometric transients for the reduction of $\mathrm{SO}_{2}$ in $\left[\mathrm{C}_{4} \mathrm{mim}\right]\left[\mathrm{NO}_{3}\right]$. The potential was stepped from 0 to $-2.0 \mathrm{~V}$.

\section{Conclusions}

Whereas for organic species, the reactions and mechanisms in RTILs have been found to be the same as in conventional solvents, the behaviour of inorganic species in RTILs is varied. The electrochemical study of iodides, oxygen, ammonia, nitrogen dioxide and sulphur dioxide, has shown that the oxidation and reduction mechanisms are the same as in conventional solvents. However, the observations of the extra reduction peak following the oxidation of $\mathrm{NH}_{3}$ (reduction of solvated proton), and the second oxidation peak for $\mathrm{NO}_{2}$ (direct oxidation of $\mathrm{N}_{2} \mathrm{O}_{4}$ ) are only possible due to the unique physical characteristics of the RTIL i.e. proton solvation ability, and wide electrochemical window. For nitrates, the electrochemical behaviour in RTILs much more closely resembles the behaviour in high temperature nitrate melts than in conventional solvents. The unique stability of $\mathrm{PCl}_{3}$ and $\mathrm{POCl}_{3}$ in the RTIL allowed the first detailed electrochemical study of these compounds in any solvent, and the suggestion that the $\mathrm{PCl}_{3}$ molecules sit in the "holes" of the ionic liquid, probably created from poor packing of asymmetric cations. This review highlights the need for more electrochemical studies of inorganic species in RTILs. 


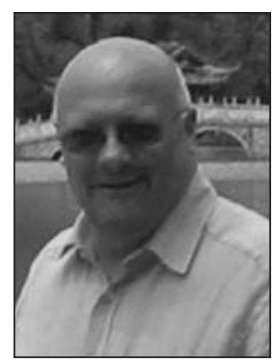

Richard Guy Compton is Professor of Chemistry at the University of Oxford and Tutor in Chemistry at St John's College. He is the editor of the Elsevier journal Electrochemistry Communications and a scientific founder of the spin-out company OxTox Limited tasked with producing electrochemical sensors for roadside drugdriving testing. He has published in excess of 800 papers and articles in refereed journals and recently co-authored the book 'Understanding Voltammetry' (World Scientific, Singapore, 2007).

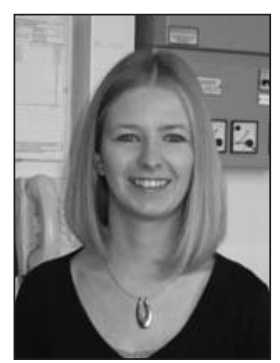

Debbie S. Silvester completed a Masters degree in Chemistry in 2005 at the University of Bristol. She spent one year of her degree as an exchange student, and worked with Professor Royce W. Murray at the University of North Carolina. She is currently a third year Ph.D student at the University of Oxford (St. John's College). Her research is centered on determining organic/inorganic reaction mechanisms, understanding the nature of protons in RTILs, and the electrochemical detection of gases.

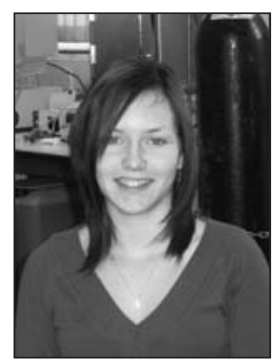

Emma I. Rogers completed a Masters degree in Chemistry with Forensic Science and Toxicology at the University of Hull in 2006, where she carried out research under the supervision of Dr Jay D. Wadhawan, a former Ph.D student of Professor Richard Compton. She is now in the second year of her Ph.D at the University of Oxford (St. John's College). Her research involves the application of RTILs in electrochemistry, in particular, the optimisation of reference electrodes for use in RTILs.

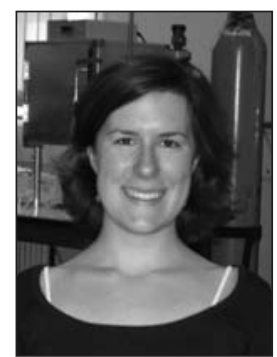

Laura E. Barrosse-Antle is a second year Ph.D. student at the University of Oxford (St. John's College), performing research on the electrochemistry of room temperature ionic liquids, currently directed at the sensing of toxic gases. She graduated from the University of Richmond, Virginia with a B.S. in Chemistry in 2006.

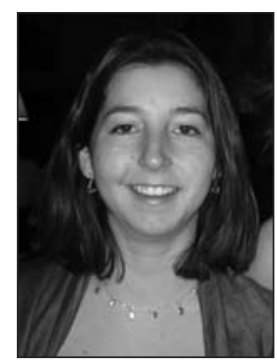

Tessa L. Broder graduated from the University of Oxford in 2007 with a Masters degree in Chemistry (University College). She carried out her final year research project under the supervision of Professor Richard Compton and focussed on determining the reaction mechanisms of inorganic compounds, and gas sensing in RTILs.

\section{References}

1. Jork, C.; Kristen, C.; Pieraccini, D.; Stark, A.; Chiappe, C.; Beste, Y. A.; Arlt, W.; J. Chem. Thermodyn. 2005, 37, 537.

2. Baker, G. A.; Baker, S. N.; Pandey, S.; Bright, F. V.; Analyst 2005, 130, 800; Forsyth, S. A.; Pringle, J. M.; MacFarlane, D. R.; Aust. J. Chem. 2004, 57, 113; Welton, T.; Chem. Rev. 1999, 99, 2071.

3. Silvester, D. S.; Broder, T. L.; Aldous, L.; Hardacre, C.; Crossley, A.; Compton, R. G.; Analyst 2007, 132, 196.

4. Earle, M. J.; Seddon, K. R.; Pure Appl. Chem. 2000, 72, 1391; Marsh, K. N.; Deev, A.; Wu, A. C.-T.; Tran, E.; Klamt, A.; Korean J. Chem. Eng. 2002, 19, 357.

5. Buzzeo, M. C.; Evans, R. G.; Compton, R. G.; ChemPhysChem 2004, 5, 1106; Silvester, D. S.; Compton, R. G.; Z. Phys. Chem. 2006, 220, 1247.

6. Lipsztajn, M.; Osteryoung, R. A.; J. Electrochem. Soc. 1983, 130, 1968; Matsumoto, K.; Hagiwara, R.; Ito, Y.; Electrochem. Solid-State Lett. 2004, 7, 41; Zein el-Abedin, S.; Endres, F.; ChemPhysChem 2006, 7, 58.

7. Abbott, A. P.; McKenzie, K. J.; Phys. Chem. Chem. Phys. 2006, 8, 4265; Endres, F.; ChemPhysChem 2002, 3, 144; Freyland, W.; Zell, C. A.; Zein el-Abedin, S.; Endres, F.; Electrochim. Acta 2003, 48, 3053; Zein el-Abedin, S.; Pölleth, M.; Meiss, S. A.; Janek, J.; Endres, F.; Green Chem. 2007, 6, 549.

8. Buzzeo, M. C.; Hardacre, C.; Compton, R. G.; ChemPhysChem 2006, 7, 176.

9. Buzzeo, M. C.; Hardacre, C.; Compton, R. G.; Anal. Chem. 2004, 76, 4583.

10. Howlett, P. C.; MacFarlane, D. R.; Hollenkamp, A. F.; Electrochem. Solid-State Lett. 2004, 7, A97.

11. McEwen, A. B.; Ngo, H. L.; LeCompte, K.; Goldman, J. L.; J. Electrochem. Soc. 1999, 146, 1687.

12. Wang, P.; Zakeeruddin, S. M.; Moser, J. E.; Grätzel, M.; J. Phys. Chem. B 2003, 107, 13280.

13. Endres, F.; Zein El-Abedin, S.; Phys. Chem. Chem. Phys. 2006, $18,2101$.

14. Evans, R. G.; Compton, R. G.; ChemPhysChem 2006, 7, 488; Evans, R. G.; Klymenko, O. V.; Hardacre, C.; Seddon, K.; Compton, R. G.; J. Electroanal. Chem. 2003, 556, 179; Evans, 
R. G.; Klymenko, O. V.; Price, P. D.; Davies, S. G.; Hardacre, C.; Compton, R. G.; ChemPhysChem 2005, 6, 526; Lagrost, C.; Carrie, D.; Vaultier, M.; Hapiot, P.; J. Phys. Chem. A 2003, 107, 745; Lagrost, C.; Preda, L.; Volanschi, E.; Hapiot, P.; J. Electroanal. Chem. 2005, 585, 1 .

15. Silvester, D. S.; Wain, A. J.; Aldous, L.; Hardacre, C.; Compton, R. G.; J. Electroanal. Chem. 2006, 596, 131.

16. Broder, T. L.; Silvester, D. S.; Aldous, L.; Hardacre, C.; Compton, R. G.; J. Phys. Chem. B 2007, 111, 7778.

17. Broder, T. L.; Silvester, D. S.; Aldous, L.; Hardacre, C.; Crossley, A.; Compton, R. G.; New J. Chem. 2007, 31, 966.

18. Ji, X.; Silvester, D. S.; Aldous, L.; Hardacre, C.; Compton, R. G.; J. Phys. Chem. C 2007, 111, 9562..

19. Silvester, D. S.; Aldous, L.; Lagunas, M. C.; Hardacre, C.; Compton, R. G.; J. Phys. Chem. B 2006, 110, 22035.

20. Shoup, D.; Szabo, A.; J. Electroanal. Chem. 1982, 140, 237.

21. Evans, R. G.; Klymenko, O. V.; Saddoughi, S. A.; Hardacre, C.; Compton, R. G.; J. Phys. Chem. B 2004, 108, 7878.

22. Sharp, M.; Electrochim. Acta 1983, 28, 301.

23. Davis, J.; Moorcroft, M. J.; Wilkins, S. J.; Compton, R. G.; Cardosi, M. F.; Analyst 2000, 125, 737; Moorcroft, M. J.; Davis, J.; Compton, R. G.; Talanta 2001, 54, 785; Pletcher, D.; Poorabed, Z.; Electrochim. Acta 1979, 24, 1253.

24. Johnson, K. E.; Zacharias, P. S.; J. Electrochem. Soc. 1977, 124, 448; Miles, M.; Fletcher, A. N.; J. Electrochem. Soc. 1980, 127, 1761; Zambonin, P. G.; J. Electroanal. Chem. 1970, 24, 365.

25. Xu, Q.; Wang, R.; Kiyobayashi, T.; Kuriyama, N.; Kobayashi, T.; J. Power Sources 2006, 155, 167.

26. Iwamoto, R. T.; Anal. Chem. 1959, 31, 955; Kolthoff, I. M.; Coetzee, J. F.; J. Am. Chem. Soc 1957, 79, 1852; Popov, A. I.; Geske, D. H.; J. Am. Chem. Soc. 1958, 80, 1340.

27. Zhang, Y.; Zheng, J. B.; Electrochim. Acta 2007, 52, 4082.

28. Aldous, L.; Silvester, D. S.; Villagran, C.; Pitner, W. R.; Compton, R. G.; Lagunas, M. C.; Hardacre, C.; New J. Chem. 2006, 30, 1576.

29. Allen, G. D.; Buzzeo, M. C.; Villagrán, C.; Hardacre, C.; Compton, R. G.; J. Electroanal. Chem. 2005, 575, 311.

30. Amigues, E.; Hardacre, C.; Keane, G.; Migaud, M.; O’Neill, M.; Chem. Commun. 2005, 1, 72 .

31. Umecky, T.; Kanakubo, M.; Ikushima, Y.; Fluid Phase Equilib. 2005, 228-229, 329.

32. Jin, X.; Yu, L.; Garcia, D.; Ren, R. X.; Zeng, X.; Anal. Chem. 2006, 78, 6980; Wang, R.; Okajima, T.; Kitamura, F.; Ohsaka, T.; Electroanalysis 2004, 16, 66; Yu, L.; Garcia, D.; Ren, R. X.; Zeng, X.; Chem. Commun. 2005, 17, 2277.

33. Savéant, J.-M.; J. Phys. Chem. C 2007, 111, 2819.

34. AlNashef, I. M.; Leonard, M. L.; Kittle, M. C.; Matthews, M. A.; Weidner, J. W.; Electrochem. Solid-State Lett. 2001, 4, D16.
35. Jain, P. S.; Lal, S.; Electrochim. Acta 1982, 27, 759.

36. Peover, M. E.; White, B. S.; Electrochim. Acta 1966, 11, 1061.

37. Buzzeo, M. C.; Klymenko, O. V.; Wadhawan, J. D.; Hardacre, C.; Seddon, K.; Compton, R. G.; J. Phys. Chem. A 2003, 107, 8872.

38. Gallagher, J. T.; Tayler, F. M.; Education in Chemistry 1967, 4, 30; Wobst, E.; Homman, G.; Friedrich, H.; Brauindustrie 1993, 78,608 .

39 de Vooys, A. C. A.; Koper, M. T. M.; van Santen, R. A.; van Veen, J. A. R.; J. Electroanal. Chem. 2001, 506, 127; Despic, A. R.; Drazic, D. M. R., P. M.; Electrochim. Acta 1966, 11, 997; López de Mishima, B. A.; Lescano, D.; Molina Holgado, T.; Mishima, H. T.; Electrochim. Acta 1997, 43, 395.

40. Barnes, K. K.; Mann, C. K.; J. Org. Chem. 1967, 32, 1479.

41. Buzzeo, M. C.; Giovanelli, D.; Lawrence, N. S.; Hardacre, C.; Seddon, K. R.; Compton, R. G.; Electroanalysis 2004, 16, 888

42. Ji, X.; Banks, C. E.; Compton, R. G.; Electroanalysis 2006, 18, 449.

43. Hoherèáková, Z.; Opekar, F.; Sens. Actuators, B 2004, 97, 379; Mizutani, Y.; Matsuda, H.; Ishiji, T.; Furuya, N.; Takahashi, K.; Sens. Actuators, B 2005, 108, 815.

44. Topol, L. E.; Osteryoung, R. A.; Christie, J. H.; J. Phys. Chem. 1966, 70, 2857.

45. McCormick, P. G.; Swofford Jr., H. S.; Anal. Chem. 1969, 41, 146.

46. Boughriet, A.; Wartel, M.; Fischer, J. C.; J. Electroanal. Chem. 1985, 190, 103; Boughriet, A.; Wartel, M.; Fischer, J. C.; Talanta 1986, 33, 385.

47. Lee, K. Y.; Amatore, C.; Kochi, J. K.; J. Phys. Chem. 1991, 95, 1285.

48. Gauthier, M.; Chamberland, A.; Bélanger, A.; Poirier, M.; J. Electrochem. Soc. 1977, 124, 1584; Hodgson, A. W. E.; Jacquinot, P.; Hauser, P. C.; Anal. Chem. 1999, 71, 2831; Skeaff, J. M.; Dubreuil, A. A.; Sens. Actuators, B 1993, 10, 161.

49. Kim, B.-S.; Park, S.-M.; J. Electrochem. Soc. 1995, 142, 26.

50. Potteau, E.; Levillian, E.; Lelieur, J.-P.; J. Electroanal. Chem. 1999, 476, 15.

51. Gardner, C. L.; Fouchard, D. T.; Fawcett, W. R.; J. Electrochem. Soc. 1981, 128, 2345.

52. Gardner, C. L.; Fouchard, D. T.; Fawcett, W. R.; J. Electrochem. Soc. 1981, 128, 2337; Martin, R. P.; Sawyer, D. T.; Inorg. Chem. 1972, 11, 2644

Received: June 19, 2007

Web Release Date: December 3, 2007 